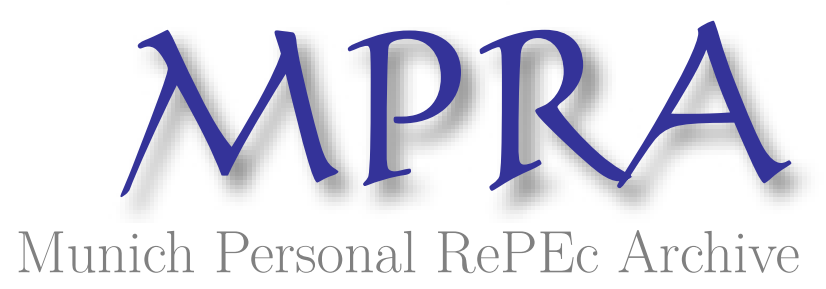

\title{
Conditional determinants of FDI in fast emerging economies: an instrumental quantile regression approach
}

Asongu, Simplice and Kodila-Tedika, Oasis

African Governance and Development Institute

1 February 2015

Online at https://mpra.ub.uni-muenchen.de/67297/

MPRA Paper No. 67297, posted 18 Oct 2015 10:28 UTC 


\section{AFRICAN GOVERNANCE AND DEVELOPMENT INSTITUTE}

\section{$\underline{\text { A G D I Working Paper }}$}

\section{WP/15/003}

Conditional determinants of FDI in fast emerging economies: an instrumental quantile regression approach

\section{Simplice A. Asongu}

African Governance and Development Institute,

Yaoundé, Cameroon.

E-mail: asongusimplice@yahoo.com

\section{Oasis Kodila-Tedika}

Department of Economics

University of Kinshasa

B.P. 832 KIN XI

Kinshasa, Democratic Republic of Congo.

oasiskodila@yahoo.fr 


\title{
AGDI Working Paper
}

Research Department

\section{Conditional determinants of FDI in fast emerging economies: an instrumental quantile regression approach}

\author{
Simplice A. Asongu ${ }^{1}$ \& Oasis Kodila-Tedika
}

February 2015

\begin{abstract}
This paper examines FDI determinants in the BRICS and MINT throughout the conditional distributions of FDI for the period 2001-2011. An instrumental variable quantile regression estimation strategy is employed based on the intuition that, the determinants are contingent on initial or existing FDI levels. The following are some of the findings established. First, FDI benefits of GDP growth are more apparent in nations with higher initial levels of FDI. Second, real GDP output would more positively influence FDI in countries where initial levels of FDI are higher. Hence, the market-seeking purposes increases FDI with a larger magnitude in Higher FDI countries. Third, the impact of trade openness has a Kuznets shape for Gross FDI and increasing tendency for Net FDI. The impact of political stability is only significant for Gross FDI in increasing order.
\end{abstract}

JEL Classification: C52; F21; F23

Keywords: Foreign direct investment; Emerging countries; Quantile regression

\section{Acknowledgement}

We are highly indebted to Apkan Uduak for sharing his dataset.

${ }^{1}$ Simplice A. Asongu is Lead economist in the Research Department of the AGDI (asongus@afridev.org). 


\section{Introduction}

Consistent with De Mello (1997) and Dupasquier \& Osakwe (2006), capital control and trade restrictive policies were implemented in many developing counties in the 1970s and 1980s in an effort to protect domestic industries. The immediate effect of such poliies was reduction in FDI, decreasing economic growth (Rodrik, 1998) and distortions in private and social returns (De Mello, 1997). These challenges led to economic reforms based on structural adjustement policies in the late 1980s and early 1990s, which entailed a mitigation of restrictions to trade and capital flows (Apkan et al., 2014; UNESCAP, 2000) ${ }^{2}$. Other developing countries confronted with an abundance of labour supply and shortage of finance also reduced restrictions to international trade and capital mobility (Asongu, 2013a, 2014a; UNCTAD ${ }^{3}$, 2013).

With the scramble for foreign land acquisitions (FLA) across the globe, a recent stream of literature on the determinants and implications of foreign direct investments (FDI) has emerged (Osabuohien, 2014, 2015; Asongu \& Nguena, 2015). The rush in FLA/FDI is not only limited to developing countries in South \& Central Asia, Latin America and Africa. It also extends to Australia, Russia and Ukraine. Notable foreign investors are of two kinds. On the one hand, we have private and public investors from Asia while on the other hand, a European private sector, consisting of hedge funds and investment banks are also playing a substantial role (UN, 2010).

A number of factors have been raised for FLA. According to Arezki et al. (2013), a debate underlying the rush draws on agricultural production structure that articulates the need for smallholder structure for poverty reduction initiatives (World Bank 2007; Lipton, 2009). This motivation is based on the exceptional poverty reduction experience by Asian nations,

\footnotetext{
${ }^{2}$ United Nations Economic and Social Commission for Asia and the Pacific.

${ }^{3}$ United Nations Conference on Trade and Development
} 
which is substantially justified by burgeoning small scale agriculture (Loayza \& Raddatz 2010; De Janvry \& Sadoulet, 2010). In another line of narrative, global soaring food prices in 2008 were met with limited flexibility in sub-Saharan Africa in terms of productivity improvement (Collier, 2008).

The beneficial effects of FDI are mutual to both domestic economies and investing companies. Potential benefits for the domestic countries include, inter alia: employment, finance and positive externalities (in terms of practice in corporate governance, managerial expertise and transfers of technology \& skills). In the same vein, the foreign company gains in terms of cheap labour, positive externalities from multilateral and bilateral policies of trade, access to market and natural resources (Akpan et al., 2014). Consistent with the narrative, a report published by UNCTAD (2013) on World Investment suggest that FDI to developing countries has been increasing substantially, accounting for about 52\% of total World FDI inflows in 2012. Among recipients, fast growing emerging nations like Brazil, India \& China are among the 20 recipients. With respect to the spread in FDI relative to geographical regions ${ }^{4}$, the following received the highest FDI in their respective regions: Nigeria in Africa, China in East Asia, Mexico in Central America, India in Southern Asia, Indonesia in SouthEastern Asia, Turkey in West Asia and Brazil in South America (World Bank, 2013). These countries represent the BRICS (Brazil, Russia, India, China \& South Africa) and MINT (Mexico, Indonesia, Nigeria \& Turkey).

As shown in Table 1 below, in 2011 the BRICS: accounted for 15\% of global GDP, and attracted 26\% of global FDI (Apkan et al., 2014; World Bank, 2013). It is interesting to note that there are common characteristics among MINT \& BRICS countries. These include, inter alia: a positive demographic change skewed toward a growing youth population, good

\footnotetext{
${ }^{4}$ Geographical regions are consistent with the UNCTAD classification.
} 
geographic locations, the Great 20 (G20) member countries (with the exception of Nigeria) and favourable FDI policies. As shown in Table 1 below, between 2001 and 2012, FDI to the MINT and BRICS countries increased to 510.4 billion in 2012 from 113.6 billion in 2001 . Within this period, the nine countries contributed $19 \%$ of global GDP, reflected $51 \%$ of the world population and accounted for 30\% of global FDI (World Bank, 2013). Other stylized facts presented in Table 1 below demonstrate the growing importance of these countries.

Table 1: Stylized facts on BRICS and MINT

\begin{tabular}{|l|l|l|l|l|l|l|l|l|l|}
\hline & $\begin{array}{l}\text { GDP } \\
\text { (constant } \\
2005 \\
\text { US\$, } \\
\text { billions) }\end{array}$ & $\begin{array}{l}\text { GDP per } \\
\text { capita } \\
\text { (constant } \\
\text { US\$) }\end{array}$ & $\begin{array}{l}\text { GDP } \\
\text { growth } \\
\text { (annual } \\
\%)\end{array}$ & $\begin{array}{l}\text { GDP } \\
\text { per } \\
\text { capita } \\
\text { growth } \\
\text { (annual } \\
\%)\end{array}$ & $\begin{array}{l}\text { FDI net } \\
\text { inflows } \\
\text { BoP, } \\
\text { current } \\
\text { US\$, } \\
\text { billions)* }\end{array}$ & $\begin{array}{l}\text { Population } \\
\text { growth } \\
\text { (annual \%) }\end{array}$ & $\begin{array}{l}\text { Population, } \\
\text { total, } \\
\text { millions }\end{array}$ & $\begin{array}{l}\text { Natural } \\
\text { resources, } \\
\text { Share of } \\
\text { GDP* }\end{array}$ & $\begin{array}{l}\text { Human } \\
\text { Development } \\
\text { Index (HDI) }\end{array}$ \\
\hline Brazil & 1136.56 & 5721.23 & 0.87 & 0.00 & 71.54 & 0.87 & 198.66 & 5.72 & 0.73 \\
\hline China & 4522.14 & 3348.01 & 7.80 & 7.28 & 280.07 & 0.49 & 1350.70 & 9.09 & 0.70 \\
\hline India & 1368.76 & 1106.80 & 3.24 & 1.94 & 32.19 & 1.26 & 1236.69 & 7.36 & 0.55 \\
\hline Indonesia & 427.47 & 1731.59 & 6.23 & 4.91 & 19.24 & 1.25 & 246.86 & 10.00 & 0.63 \\
\hline Mexico & 997.10 & 8250.87 & 3.92 & 2.65 & 21.50 & 1.24 & 120.85 & 9.02 & 0.78 \\
\hline Nigeria & 177.67 & 1052.34 & 6.55 & 3.62 & 8.84 & 2.79 & 168.83 & 35.77 & 0.47 \\
\hline Russia & 980.91 & 6834.01 & 3.44 & 3.03 & 55.08 & 0.40 & 143.53 & 22.03 & 0.79 \\
\hline South Africa & 307.31 & 6003.46 & 2.55 & 1.34 & 5.89 & 1.18 & 51.19 & 10.64 & 0.63 \\
\hline Turkey & 628.43 & 8492.61 & 2.24 & 0.94 & 16.05 & 1.28 & 74.00 & 0.84 & 0.72 \\
\hline *2011 data & & & & & & & & \\
\hline Source & & & & & & & & \\
\hline
\end{tabular}

Source of data: UNDP (2013), World Bank (2013) and Akpan et al. (2014)

Despite the growing relevance of MINT and BRICS in shaping of the world economy on the one hand and determining the direction of FDI to developing countries on the oher hand, very few studies have examined factors that attract FDI to these countries. Vijayakumar et al. (2010) have assessed the determiannts of FDI in BRICS using panel data analysis for the period 1975-2007 and established that labour cost, market size, gross capital formation and infrastructure have positive impacts whereas the effects of inflation and trade openness are insignificant. Jadhav \& Katti (2012) establish that: regulation quality , government 
effectiveness (corruption-control, political instability and voice \& accountability) have positive (negative) impacts on FDI. Using the same periodicity, Jadhav (2012) find that FDI is for the most part market-oriented because the availability of resources has a negative effect whereas openness to trade, rule of law and market size have the opposite impact. Akpan et al. (2014) which is closest to this study have used data for the period 2001-2011 to assess the effect in BRICS and MINT countries and concluded that while the effects of institutional quality and natural resources are insignificant, the impacts of trade openness, market size and infrastrucure have positive roles in determinig FDI. The above studies do not account for endogeneity. Moreover, the determinants are conditioned on the mean of the FDI distribution.

We complement the exisiting literature in a threefold manner. First, we investigate determinants of FDI throughout the conditional distributions of FDI. The motivation for this line of empirical strategy is that even among fast growing developing economies, the determinants may still depend on initial or existing levels of FDI. We employ a Quantile Regression (QR) strategy for this purpose. Second, the issue of endogeneity is handled by instrumenting the determinants with their first-lags. Third, like in Apkan et al. (2014), we complement BRICS with MINT countries.

The rest of the study is organised as follows. Section 2 presents the theoretical and empirical literature. The data and methodolodgy is covered in Section 3. Section 4 presents the empirical analysis and discussion of results. We concluded with Section 5.

\section{Theoretical and empirical evidence}

\subsection{Theoretical highlights}

Consistent with Apkan et al. (2014), the interest of multinational companies for investing abroad is based on a plethora of theoretical underpinnings that incorporated, inter alia: the neoclassical theory of trade, eclectic paradigm, market imperfections and product 
lifecycle theory. The theoretical underpinnings substantially draw on a model from Heskscher-Ohlin which sustains that capital flows and opportunities of trade between two nations are relatively contingent on endowment in factors of production. In this light, investment from multinational companies take advantage of lower production cost and better return to investment opportunities. According to the theory of market imperfection, multinational companies can relocate production activities or locate to other nations (to gain from economies of scale, government incentives \& ownership externalities) because of imperfect markets (Eiteman et al., 2007; Kindlerberger, 1969). Consistent with the theory on imperfections, market imperfections in the domestic economies motivate multinational corporations to engage in further processes of enhancing their assets (Hennart, 1982; Buckley \& Casson, 1976; Shapiro, 2006).

\subsection{Empirical evidence: determinants of FDI}

An interesting empirical literature has documented FDI/FLA determinants. These factors according to Akpan et al. (2014) are contingent on: context of papers, variable measurement and periodicity of investigation (Buchanan et al., 2012; Ranjan \& Agrawal, 2011; Hajzler, 2014; Moosa \& Cardak, 2006; Asiedu, 2006; Sekkat \& VeganzonesVaroudakis, 2007; Asiedu, 2002; Moosa, 2002). In accordance with Asongu \& Nguena (2015), we present the existing empirical literature in six main strands, notably: business climate quality (return, institutions, trade and infrastructure), issues with security in tenure law, bad governance, resource-interests, regional features and global economic meltdowns.

Business climate factors in the first strand include: incentives and labour (Vijayakumar et al., 2010; Asongu, 2014b; Tuomi, 2011); trade, infrastructure and size of domestic market (Kinda, 2010; Bartels et al, 2009; Vijayakumar et al., 2010; Büthe \& Milner, 2008; Jadhav, 2012; Anyanwu, 2012; Darley, 2012; Akpan et al., 2014; Bartels et al., 2014); return to capital \& infrastructural quality (Asiedu, 2002) and; time, market factors \&local 
partners (Amendolagine et al., 2013). Institutional factors entail: democracy (Asiedu \& Lien, 2011), economic governance (Jadhav \& Katti, 2012), political stability (Busse \& Hefeker, 2007), the control of corruption (Wei, 2010; De Maria, 2010) and a general appealing institutional environment (Bartels et al., 2014; Hayakawa et al., 2013; Abdioglu et al., 2013; Asongu, 2012; Cleeve, 2012; Tuomi, 2011; Kinda, 2010; Neumayer \& Spess, 2005; Gastanaga et al., 1998).

The element of business climate in the second strand has been substantially documented by Areski et al. (2013). Here narratives are conflicting because, while bad governance is found to be a pulling factor in certain cases, it is not the case for others. Moreover, whereas Kolstad \& Wiig (2011) have established poor business climate conditions like bad governance as the principal factor determining the location of foreign Chinese investments in Africa, Asongu \& Aminkeng (2013) have presented a more balanced narrative, citing that Western nations/corporations as much as China, are interested in doing business with any country as long as strategic interest is at play.

Concerns about tenure security which constitute the third stand have been documented in the interesting literature on FLA (Arezki et al., 2013; UN, 2010). Accordingly, the Economic Commission for Africa (2014), Ingwe et al. (2010) and Okoth-Ogendo, (2008) have identified the significant role of land tenure systems in food security. Wouterse et al. (2011) have most eloquently articulated the concern: "taken away the land of peasants which are possessed on communal tenure systems that starkly contrast with official land titles related to 'indigenous colonialist' controlled neoliberal capitalist systems, who have used various forms of manipulation in the past to alienate Africans from their land" (Asongu \& Nguena, 2014, p.4). The position is confirmed by inter alia: German et al. (2011) who establish that FLA do not protect customary rights; Thaler (2013) on foreign investment strategically targeting countries with weak tenure laws; Liu (2013) on the substantial risk FLA 
exert on the local population and Osabuohien (2014) concluding that FLA agreements are not influenced by local institutions because of very dictatorial State power.

In the fourth stream, we find resource-seeking interest as a fundamental driver of FDI (Lay \& Nolte, 2014; Aleksynska \& Havrylchyk, 2013). Jadhav (2012) and Rogmans \& Ebbers (2013) have shown that natural resources availability is negatively linked to FDI when protectionist policies are in domestic economies. This narrative is not mainstream because Lay \& Nolte (2014) after extending the interesting literature by Arezki et al. (2013) confirm the positive drive of resource abundance in FDI location decisions. However, there is need for a more balanced debate over which countries are more resource-thirty. Asongu \& Aminkeng (2013) have debunked the Kostad \& Wiig (2011) perspective of a resource-hungry China by concluding that Western nations/corporations are also as much resource-hungry.

The fifth strand argues that global shocks such as financial and food crises are also playing a substantial role in driving FLA/FDI, especially for agricultural motives (Wouterse et al., 2011). According to the narrative, in the aftermath of the 2008 food crisis, nations that substantially depended on the importation of food began purchasing land abroad to insure domestic security in food supply in event of future crisis. In essence, the 2008 crisis was fuelled by about 25 nations imposing restrictions to food exports. This motivated private sectors to begin engaging in speculative investments (Clapp, 2013; Isakson, 2013; Fairbairn, 2013). Financial institutions concerned with this speculative investment and setting-up agricultural funds include: Deutsche Bank in Germany; Goldman Sachs \& Black Rock in the USA and Knight Frank in the UK. Some other global dynamics advanced are growing trends of economic prosperity in emerging countries and evolving strategic relevance of biofuels (German et al., 2011). 
The sixth strand highlights the importance of regional factors. Whereas Asiedu (2002) from a broad perspective has concluded that sub-Saharan Africa (SSA) is less inclined to attract FDI due to her geographical location, Anyanwu (2012) has contradicted the findings by concluding from an African comparative analysis that the Eastern and Southern regions in the continent attract more FDI. Other regional factors favouring FDI/FLA in SSA include: well structured North-South FDI strategic agreements (Aleksynska \& Havrylchyk, 2013), the comparative low usage of water supplies in the sub-continent which is currently around $2 \%$ (UN, 2010), strategies of non-interference by emerging nations like China (Yin \& Vaschetto, 2011) and presence of local partners from colonial heritage (Amendolagine et al., 2013).

\section{Data and Methodology}

\subsection{Data}

We investigate a panel of nine fast growing developing counties called the BRICS (Brazil, Russia, India, China \& South Africa) and MINT (Mexico, Indonesia, Nigeria \& Turkey) for the period 2001-2011. Consistent with Apkan et al. (2014), two main dependent variables are employed, notably: Gross FDI and Net FDI. It should be noted that the choice of dependent variables by Apkan et al. (2014) is consistent with the underlying literature documenting the use of net FDI inflows (Jadhav, 2002), unidirectional inflow to domestic economies (Rogmans \& Ebbers, 2013), ratio of net FDI flows as a \% of GDP (Asiedu, 2002) or ratio of FDI inflows as a \% of GDP (Suliman \& Mollick, 2009).

The FDI determiannts we retain which have been discussed in the above sections are consistent with UNCTAD's FDI classification presented in Table 2 below. The explanatory variables retained include: infrastructure, inflation, private credit, trade openness, political stability, natural resources, GDP growth and real GDP. But for inflation, we expect the determinants to positively affect FDI. However, it should be noted that the potentially 
negative incidence of inflation is contingent on the degree of inflation. Accordingly, low and stable inflation projects a positive economic outlook which is an incentive for FDI.

Table 2: UNCTAD's Classification of FDI determinants

\begin{tabular}{|l|l|}
\hline Determining Variables & Examples \\
\hline Policy variables & $\begin{array}{l}\text { Tax policy, trade policy, privatization policy, } \\
\text { macroeconomic policy }\end{array}$ \\
\hline Business variables & Investment incentives \\
\hline Market-related economic determinants & Market size, market growth, market structure \\
\hline Resource-related economic determinants & Raw materials, labor cost, technology costs, labor \\
\hline Efficiency-related economic determinants & $\begin{array}{l}\text { Transport and communication con } \\
\text { productivity }\end{array}$ \\
\hline
\end{tabular}

Source: UNCTAD (2002) and Akpan et al. (2014)

Table 3 below presents the definitions and summary statistics of the variables that are obtained from the World Development Indicators and World Governance Indicators databases of the World Bank, consistent with Apkan et al. (2014). The summary statistics of the variables shows that they are quite comparable. From the variations, we can be confident reasonable estimated linkages would emerge.

Table 3: Definition of variables and Summary Statistics

\begin{tabular}{lccccc}
\hline Variable(s) & Mean & S.D & Min & Max & Obs \\
\hline Net Foreign Direct Investment (NFDI) & 28.979 & 46.359 & -2.977 & 280.07 & 99 \\
Foreign Direct Investment (FDI) & 2.402 & 1.348 & -1.855 & 6.136 & 99 \\
GDP Growth (GDPg) & 5.351 & 3.789 & -7.820 & 14.200 & 99 \\
Real GDP (constant of 2005 US billions) (log) & 6.346 & 0.886 & 4.260 & 8.341 & 99 \\
Infrastructure (Number of mobile phones per 100 people) & 52.433 & 39.220 & 0.210 & 179.31 & 99 \\
Bank Credit (on GDP) & 85.019 & 63.492 & 4.909 & 201.58 & 99 \\
Natural resources (on GDP) & 9.003 & 8.110 & 0.294 & 38.410 & 99 \\
Inflation (Consumer Price Index) & 8.580 & 7.519 & -0.765 & 54.400 & 99 \\
Trade Openness (Import + Exports on GDP) & 0.514 & 0.128 & 0.225 & 0.856 & 99 \\
Political Stability & -0.826 & 0.613 & -2.193 & 0.286 & 99 \\
\hline
\end{tabular}

S.D: Standard Deviation. Min: Minimum. Max: Maximum. Obs: Observations.

\subsection{Methodology}

Consistent with the underlying literature on conditional determinants (Billger \& Goel, 2009; Asongu, 2013b), in order to determine if existing levels in FDI affect the determinants of FDI in fast developing countries, we employ a quantile regression (QR) approach. It 
consists of determinants of FDI differs throughout the conditional distributions of FDI (Keonker \& Hallock, 2001).

Previous studies on determinants have reported estimated parameters at the conditional mean of FDI (Apkan et al., 2014). While mean efects are worthwhile in certain cases, we extend the underlying study by using QR. While Ordinary Least Squares (OLS) assumes that FDI and the error terms are distributed normally, the QR approach is not based on such an assumption of a normally distributed error term. Hence, the technique enables us to investigate the deteminants with particular emphasis on the best and worse candidates among fast growing developing economies. Accordingly, with QR, parameter estimates are presented at multiple points of the conditional distribution of FDI (Koenker \& Bassett, 1978).

This QR technique has been substantially employed in recent literature on conditional determinants (Okada \& Samreth, 2012; Asongu, 2014b; Billger \& Goel, 2009). However, the common drawback among these applications is the issue of endogeneity. We account for it by employing an instrumental variable (IV) QR technique. Hence, the determinants are instrumented with their first lags. The fitted values are then used in the QR estimations as exogenous variables.

$x_{i, t}=\alpha+\delta_{j}\left(x_{i, t-1}\right)+\varepsilon_{i, t}$

Where: $x_{i, t}$ is a FDI determinant for country $i$ at period $t ; \alpha$ is a constant and $\varepsilon_{i, t}$ the error term. The instrumentation in Eq. (1) is based on first lags. The estimations processes are based on Heteroscedasticity and Autocorrelation Consistent (HAC) standard errors.

The $\theta$ th quantile estimator of FDI is obtained by solving for the following optimization problem, which is presented without subscripts for simplicity in Eq. (2)

$\min _{\beta \in R^{k}}\left[\sum_{i \in\left\{i: y_{i} \geq x_{i^{\prime} \beta}\right\}} \theta\left|y_{i}-x_{i^{\prime}} \beta\right|+\sum_{i \in\left\{i: y_{i} \geq x_{i^{\prime}} \beta\right.}(1-\theta)\left|y_{i}-x_{i^{\prime}} \beta\right|\right]$ 
Where $\theta \in(0,1)$. As opposed to OLS which is fundamentally based on minimizing the sum of squared residuals, with $\mathrm{QR}$, the weighted sum of absolute deviations are minimised. For example, the $25^{\text {th }}$ or $75^{\text {th }}$ quantiles (with $\theta=0.25$ or 0.75 respectively) are assessed by approximately weighing the residuals. The conditional quantile of FDI or $y_{i}$ given $x_{i}$ is:

$$
Q_{y}\left(\theta / x_{i}\right)=x_{i} \beta_{\theta}
$$

where unique slope parameters are modelled for each $\theta$ th specific quantile. This formulation is analogous to $E(y / x)=x^{\prime} \beta$ in the OLS slope where parameters are investigated only at the mean of the conditional distribution of FDI. For the model in Eq. (3), the dependent variable $y_{i}$ is the FDI indicator while $x_{i}$ contains a constant term, infrastructure, inflation, private credit, trade openness, political stability, natural resources, GDP growth and real $G D P$. For robustness purposes, we report the findings for Least Absolute Deviations (LAD) which should theoretically correspond to results of the $0.5^{\text {th }}$ quantile.

The specifications in Eq. (3) control for multicollinearity and overparameterization issues. Table 4 below has enabled us to control for these concerns. Accordingly, from a preliminary assessment of the correlation coefficients, the issues are not apparent among the instrumented independent variables.

Table 4: Correlation matrix on the loadings (for FDI)

\begin{tabular}{rrrrrrrrrrrl}
\hline IVInfra & IVInfla & IVCredit & IVTrade & IVPolS & IVNres & IVGDPg & IVRGDP & FDI & \multicolumn{1}{l}{ NFDI } & & \\
\cline { 1 - 8 } 1.000 & -0.081 & 0.234 & 0.203 & 0.303 & 0.273 & -0.216 & 0.193 & 0.134 & 0.157 & IVInfra \\
& 1.000 & 0.010 & -0.081 & -0.268 & 0.077 & -0.230 & -0.343 & -0.256 & -0.303 & IVInfla \\
& & 1.000 & -0.140 & 0.551 & -0.490 & 0.019 & 0.139 & -0.118 & 0.175 & IVCredit \\
& & & 1.000 & -0.344 & 0.336 & 0.263 & -0.177 & 0.308 & 0.204 & IVTrade \\
& & & & 1.000 & -0.240 & -0.179 & 0.467 & 0.035 & 0.231 & IVPolS \\
& & & & & 1.000 & 0.065 & 0.069 & 0.132 & 0.039 & IVNres \\
& & & & & & 1.000 & 0.224 & 0.357 & 0.416 & IVGDPg \\
& & & & & & 1.000 & 0.243 & 0.696 & IVRGDP \\
& & & & & & & 1.000 & 0.448 & FDI \\
& & & & & & & & 1.000 & NFDI
\end{tabular}

IV: Instrumented Variable. Infra: Infrastructure. Infla: Inflation. Credit: Domestic Credit. PolS: Political Stability. Nres: Natural resources. FDIgdp: Gross FDI. NFDI: Net FDI. GDPg: GDP growth rate. RGDP: Real GDP. 


\section{Empirical results}

Table 5 provides results in terms of OLS, LAD and QR estimates. OLS results present the baseline findings on mean impact which we compare with those of LAD and distinct quantiles in the conditional distributions of FDI. While Panel A shows findings based on Gross FDI, the corresponding results in Panel B are based on Net FDI. The estimations are based on robust standard errors. When interpreting the signs and magnitudes of estimated coefficients, it is important to note that, lower quantiles of the FDI conditional distributions denote countries with lower initial levels of FDI.

The following findings are established. First, baseline OLS results are different in significance and magnitude across specifications. This justifies the employment of an estimation technique that assesses determinants throughout the conditional distributions of FDI. Second, the LAD findings are consistently the same as estimates at the 0.5 th quantile. We deliberately used the GRETL software for LAD estimates and Stata for the QR to assess this consistency. Third, GDP increases FDI with the magnitude increasing in the Top quantiles. There is an increase from the $0.75^{\text {th }}$ to the $0.90^{\text {th }}$ quantile for Gross FDI and from the $0.25^{\text {th }}$ to the $0.75^{\text {th }}$ quantile for Net FDI. Fourth, Real GDP increases FDI in increasing (decreasing) magnitude for Net FDI (Gross FDI). While it decreases for Gross FDI from the 0.10 to the $0.50^{\text {th }}$ quantile and increases from 0.10 to the 0.75 quantile in Panel B on Net FDI. Fifth, the negative effect of Natural resources and positive effect of Infrastructure are only significant in the $0.25^{\text {th }}$ and $0.75^{\text {th }}$ quantiles for Net FDI. Sixth, the effect of inflation is not significant across specification and dependent variables. This is consistent with Vijayakumar et al. (2010) on the BRICS. Seventh, the effect of domestic credit is unexpectedly negative on Gross FDI and insignificant on Net FDI. Eighth, the impact of trade openness: has a Kuznets shape from the $0.25^{\text {th }}$ to the $0.75^{\text {th }}$ quantile for Gross FDI and increases for Net FDI. Ninth, 
the impact of political stability is only significant for Gross FDI in increasing order $\left(0.10^{\text {th }}\right.$, $\left.0.25^{\text {th }} \& 0.90^{\text {th }}\right)$.

Table 5: Determinants of Foreign Direct Investment (FDI)

\begin{tabular}{|c|c|c|c|c|c|c|c|}
\hline & \multicolumn{7}{|c|}{ Panel A: Gross FDI } \\
\hline & OLS & LAD & Q.10 & Q.25 & Q.50 & Q.75 & Q.90 \\
\hline Constant & $\begin{array}{l}-0.804 \\
(0.697)\end{array}$ & $\begin{array}{l}-3.433 \\
(0.167)\end{array}$ & $\begin{array}{l}-3.189 * \\
(0.053)\end{array}$ & $\begin{array}{l}-3.60 * * * * \\
(0.001)\end{array}$ & $\begin{array}{l}-3.433 * \\
(0.076)\end{array}$ & $\begin{array}{l}1.227 \\
(0.514)\end{array}$ & $\begin{array}{l}1.452 \\
(0.701)\end{array}$ \\
\hline GDP growth & $\begin{array}{l}0.252 * * * * \\
(0.000)\end{array}$ & $\begin{array}{l}0.173 \\
(0.173)\end{array}$ & $\begin{array}{l}0.079 \\
(0.250\end{array}$ & $\begin{array}{l}0.142 * * \\
(0.026)\end{array}$ & $\begin{array}{l}0.173 \\
(0.130)\end{array}$ & $\begin{array}{l}\mathbf{0 . 3 3 5} * * * \\
(\mathbf{0 . 0 0 1 )}\end{array}$ & $\begin{array}{l}0.374 * \\
(0.081)\end{array}$ \\
\hline Real GDP & $\begin{array}{l}0.174 \\
(0.552)\end{array}$ & $\begin{array}{l}0.531 \\
(0.129)\end{array}$ & $\begin{array}{l}\mathbf{0 . 6 6 7 * * * *} \\
(0.007)\end{array}$ & $\begin{array}{l}\text { 0.618**** } \\
(\mathbf{0 . 0 0 0 )}\end{array}$ & $\begin{array}{l}0.531 * * \\
(0.026)\end{array}$ & $\begin{array}{l}-0.086 \\
(0.704)\end{array}$ & $\begin{array}{l}-0.062 \\
(0.886)\end{array}$ \\
\hline Nresources & $\begin{array}{l}-0.026 \\
(0.217)\end{array}$ & $\begin{array}{l}-0.031 \\
(0.312)\end{array}$ & $\begin{array}{l}-0.005 \\
(0.813)\end{array}$ & $\begin{array}{l}-0.001 \\
(0.919)\end{array}$ & $\begin{array}{l}-0.031 \\
(0.923)\end{array}$ & $\begin{array}{l}-0.024 \\
(0.334)\end{array}$ & $\begin{array}{l}-0.032 \\
(0.232)\end{array}$ \\
\hline Infrastructure & $\begin{array}{l}0.005 \\
(0.064)\end{array}$ & $\begin{array}{l}0.003 \\
(0.487)\end{array}$ & $\begin{array}{l}0.001 \\
(0.688)\end{array}$ & $\begin{array}{l}0.003 \\
(0.243)\end{array}$ & $\begin{array}{l}0.003 \\
(0.550)\end{array}$ & $\begin{array}{l}0.006 \\
(0.119)\end{array}$ & $\begin{array}{l}0.007 \\
(0.317)\end{array}$ \\
\hline Inflation & $\begin{array}{l}-0.004 \\
(0.858)\end{array}$ & $\begin{array}{l}0.003 \\
(0.956)\end{array}$ & $\begin{array}{l}0.013 \\
(0.637)\end{array}$ & $\begin{array}{l}-0.006 \\
(0.723)\end{array}$ & $\begin{array}{l}0.003 \\
(0.923)\end{array}$ & $\begin{array}{l}-0.005 \\
(0.793)\end{array}$ & $\begin{array}{l}0.022 \\
(0.441)\end{array}$ \\
\hline Credit & $\begin{array}{l}-0.006 \\
(0.065)\end{array}$ & $\begin{array}{l}-0.004 \\
(0.221)\end{array}$ & $\begin{array}{l}-0.007 * \\
(0.074)\end{array}$ & $\begin{array}{l}-0.005 * * \\
(0.026)\end{array}$ & $\begin{array}{l}-0.004 \\
(0.218)\end{array}$ & $\begin{array}{l}-0.007 * * \\
(0.012)\end{array}$ & $\begin{array}{l}-0.010 * \\
(0.055)\end{array}$ \\
\hline Trade & $\begin{array}{l}\text { 3.049* } \\
(0.065)\end{array}$ & $\begin{array}{l}4.158 * * \\
(0.029)\end{array}$ & $\begin{array}{l}1.626 \\
(0.409)\end{array}$ & $\begin{array}{l}3.026 * * * * \\
(0.002)\end{array}$ & $\begin{array}{l}4.158 * * \\
(0.022)\end{array}$ & $\begin{array}{l}3.08 * * \\
(0.048)\end{array}$ & $\begin{array}{l}3.657 \\
(0.295)\end{array}$ \\
\hline Political Stability & $\begin{array}{l}0.495 \\
(0.126)\end{array}$ & $\begin{array}{l}0.475 \\
(0.307)\end{array}$ & $\begin{array}{l}0.847 * * \\
(0.048)\end{array}$ & $\begin{array}{l}0.923 * * * \\
(0.000)\end{array}$ & $\begin{array}{l}0.475 \\
(0.301)\end{array}$ & $\begin{array}{l}0.508 \\
(0.125)\end{array}$ & $\begin{array}{l}0.979 * \\
(0.084)\end{array}$ \\
\hline $\mathrm{R}^{2}$ & 0.231 & --- & 0.315 & 0.285 & 0.189 & 0.188 & 0.267 \\
\hline Fisher & $4.353 * * *$ & --- & --- & --- & --- & --- & --- \\
\hline Log-likelihood & -128.93 & -134.018 & --- & --- & --- & --- & --- \\
\hline Observations & 90 & 90 & 90 & 90 & 90 & 90 & 90 \\
\hline
\end{tabular}

\begin{tabular}{|c|c|c|c|c|c|c|c|}
\hline & OLS & LAD & Q.10 & Q.25 & Q.50 & Q.75 & Q.90 \\
\hline Constant & $\begin{array}{l}-325 * * * * \\
(0.000)\end{array}$ & $\begin{array}{l}-180 \text { **** } \\
(0.006)\end{array}$ & $\begin{array}{l}-133 * * * \\
(0.000)\end{array}$ & $\begin{array}{l}-123 * * * \\
(0.000)\end{array}$ & $\begin{array}{l}-180 * * * \\
(0.000)\end{array}$ & $\begin{array}{l}-297 * * * \\
(0.000)\end{array}$ & $\begin{array}{l}-335.97 \\
(0.541)\end{array}$ \\
\hline GDP growth & $\begin{array}{l}4.812 * * \\
(0.018)\end{array}$ & $\begin{array}{l}2.613 \\
(0.232)\end{array}$ & $\begin{array}{l}2.280 * * \\
(0.036)\end{array}$ & $\begin{array}{l}1.411 * * \\
(0.014)\end{array}$ & $\begin{array}{l}2.613 * * \\
(0.024)\end{array}$ & $\begin{array}{l}7.177 * * * \\
(0.006)\end{array}$ & $\begin{array}{l}6.933 \\
(0.574)\end{array}$ \\
\hline Real GDP & $\begin{array}{l}\text { 39.89**** } \\
(\mathbf{0 . 0 0 0 )}\end{array}$ & $\begin{array}{l}\text { 23.53**** } \\
(\mathbf{0 . 0 0 1 )}\end{array}$ & $\begin{array}{l}\text { 17.25**** } \\
(\mathbf{0 . 0 0 0 )}\end{array}$ & $\begin{array}{l}\text { 17.56**** } \\
(\mathbf{0 . 0 0 0 )}\end{array}$ & $\begin{array}{l}23.53 * * * \\
(\mathbf{0 . 0 0 0 )}\end{array}$ & $\begin{array}{l}37.67 * * * * \\
(\mathbf{0 . 0 0 0 )}\end{array}$ & $\begin{array}{l}43.924 \\
(0.506)\end{array}$ \\
\hline Nresources & $\begin{array}{l}-0.643 \\
(0.299)\end{array}$ & $\begin{array}{l}-0.306 \\
(0.524)\end{array}$ & $\begin{array}{l}-0.156 \\
(0.599)\end{array}$ & $\begin{array}{l}-0.300 * \\
(0.077)\end{array}$ & $\begin{array}{l}-0.306 \\
(0.324)\end{array}$ & $\begin{array}{l}-1.41 * * * \\
(0.001)\end{array}$ & $\begin{array}{l}-2.062 \\
(0.491)\end{array}$ \\
\hline Infrastructure & $\begin{array}{l}0.009 \\
(0.921)\end{array}$ & $\begin{array}{l}0.011 \\
(0.908)\end{array}$ & $\begin{array}{l}0.070 \\
(0.112)\end{array}$ & $\begin{array}{l}0.071 * * * \\
(0.009)\end{array}$ & $\begin{array}{l}0.011 \\
(0.841)\end{array}$ & $\begin{array}{l}0.216 * * \\
(0.042)\end{array}$ & $\begin{array}{l}0.155 \\
(0.821)\end{array}$ \\
\hline Inflation & $\begin{array}{l}0.082 \\
(0.699)\end{array}$ & $\begin{array}{l}-0.327 \\
(0.559)\end{array}$ & $\begin{array}{l}0.035 \\
(0.942)\end{array}$ & $\begin{array}{l}-0.076 \\
(0.654)\end{array}$ & $\begin{array}{l}-0.327 \\
(0.313)\end{array}$ & $\begin{array}{l}0.543 \\
(0.277)\end{array}$ & $\begin{array}{l}0.299 \\
(0.947)\end{array}$ \\
\hline Credit & $\begin{array}{l}0.067 \\
(0.546)\end{array}$ & $\begin{array}{l}0.007 \\
(0.911)\end{array}$ & $\begin{array}{l}-0.015 \\
(0.729)\end{array}$ & $\begin{array}{l}-0.031 \\
(0.152)\end{array}$ & $\begin{array}{l}0.007 \\
(0.853)\end{array}$ & $\begin{array}{l}-0.018 \\
(0.799)\end{array}$ & $\begin{array}{l}0.015 \\
(0.981)\end{array}$ \\
\hline Trade & $\begin{array}{l}\text { 135.02*** } \\
(0.011)\end{array}$ & $\begin{array}{l}\text { 79.329** } \\
(0.049)\end{array}$ & $\begin{array}{l}\text { 43.85*** } \\
(0.048)\end{array}$ & $\begin{array}{l}41.62 * * * \\
(0.000)\end{array}$ & $\begin{array}{l}\text { 79.32*** } \\
(0.000)\end{array}$ & $\begin{array}{l}102.2^{* * * *} \\
(0.004)\end{array}$ & $\begin{array}{l}122.22 \\
(0.604)\end{array}$ \\
\hline Political Stability & $\begin{array}{l}-3.573 \\
(0.751)\end{array}$ & $\begin{array}{l}0.311 \\
(0.953)\end{array}$ & $\begin{array}{l}3.166 \\
(0.448)\end{array}$ & $\begin{array}{l}2.097 \\
(0.438)\end{array}$ & $\begin{array}{l}0.311 \\
(0.941)\end{array}$ & $\begin{array}{l}-3.313 \\
(0.663)\end{array}$ & $\begin{array}{l}-17.668 \\
(0.768)\end{array}$ \\
\hline $\mathrm{R}^{2}$ & 0.609 & --- & 0.277 & 0.316 & 0.352 & 0.434 & 0.527 \\
\hline Fisher & $18.38 * * *$ & --- & --- & --- & --- & --- & --- \\
\hline Log-likelihood & -429.21 & -402.105 & --- & --- & --- & --- & --- \\
\hline Observations & 90 & 90 & 90 & 90 & 90 & 90 & 90 \\
\hline
\end{tabular}

***; ****: significance levels of 1\%, 5\% and 10\% respectively. GDP: Gross Domestic Product. Nresources: Natural Resources. Lower quantiles (e.g., Q 0.1) signify nations where FDI is least. OLS: Ordinary Least Squares. LAD: Least Absolute Deviations. R² is Adjusted for OLS and Pseudo for QR (Quantile Regression). 


\section{Concluding implications}

Privatisation policies engaged by many developing countries have failed to deliver the much needed FDI (Rolfe \& Woodward, 2004). The need for FDI has also been articulated in recent population development literature. It has concluded that unemployment externalities arising from burgeoning population (especially in Africa) would only be handled by public investmetn unless efforts are initiated to attract alternative forms of investment.

This paper has complemented the underlying literaure on FDI in developing countries by assesing the determinants of FDI in nine fast growing developing countries, notably: the BRICS (Brazil, Russia, India, China \& South Africa) and MINT (Mexico, Indonesia, Nigeria \& Turkey). Two main contributions have been made to the underlying literature. First, we have investigated determinants of FDI throughout the conditional distributions of FDI. The motivation for this line of empirical strategy is that even among fast growing developing economies, the determinants of may still depend on intiial levels of FDI. We have employed a Quantile Regression (QR) strategy for this purpose. Second, the issue of endogeneity has been handled by instrumenting the determinants with their first-lags. We have had findings with interesting policy implications.

First, the fact that OLS estimates are different in significance and magnitude across specifications has a number of interesting implications. It implies that factors that influence FDI in the fast growing developing economies differ with respect to initial levels of FDI. Accordingly, countries with high, low or medium initial levels in FDI respond differently to the underlying determinants of investments from multinational corporations. Hence, blanket FDI targeting policies may not be effective unless they are contingent on initial foreign investment levels and tailored differently across high-FDI and low-FDI fast growing developing economies. Overall, this justifies the underlying motivation of the present study, 
which has steered clear of past studies by assessing determinants throughout the conditional distributions of FDI.

Second, we have established that GDP increases FDI with the magnitude increasing across specifications (Low quantiles to Top quantiles). Accordingly, there is an increase from the $0.75^{\text {th }}$ to the $0.90^{\text {th }}$ quantile for Gross FDI and from the $0.25^{\text {th }}$ to the $0.75^{\text {th }}$ quantile for Net FDI. This implies countries already experiencing higher levels of FDI would benefit more from the Growth effects of FDI compared to countries with lower initial levels of FDI. Hence, without distinguishing the type of FDI, there is evidence of a threshold effect from the $0.25^{\text {th }}$ to the $0.90^{\text {th }}$ quantile. As a policy implication, the FDI benefits of growth are more apparent in higher FDI nations among fast growing economies.

Third, we have established that, while Real GDP increases Net FDI in increasing magnitude $\left(0.10^{\text {th }}\right.$ to $0.75^{\text {th }}$ quantile $)$, it decreases Gross FDI in increasing magnitude $\left(0.10^{\text {th }}\right.$ to $0.5^{\text {th }}$ quantile). Whereas the difference in increasing magnitude is about $20.42(37.67-17.25)$, the variation in decreasing magnitude is $0.136(0.667-0.531)$. Hence, the FDI threshold effect of GDP growth is broadly confirmed relative to Real GDP owing to variations in the direction of increasing positive versus increasing negative magnitude. This further implies, Output would more positively influence FDI in countries where initial levels of FDI are higher. Since market market-size is measured by real GDP (see Jadhav \& Katti, 2012; Apkan et al., 2014), the market-seeking purposes increases FDI with a magnitude higher in countries with substantial initial levels of FDI.

The selective negative effect of Natural resources and positive effect of Infrastructure in the $0.25^{\text {th }}$ and $0.75^{\text {th }}$ quantiles for Net FDI means that only a few countries in the MINT and BRICS have contributed to the results in the underlying literature. Accordingly, the insignificant effect of Natural resources and positive impact of Infrastructure from Apkan et al. (2014) who have used the same dependent variable is substantially driven by a few 
countries in the bottom and top quantiles. The negative impact of Natural resources which is consistent with the findings of Jadhav (2012) on the BRICS suggest that this sub-sample may be driving the negative effect. On the same vein, the positive impact of Infrastructure is in accordance with Vijayakumar et al. (2010).

The negative effect of domestic credit on Gross FDI implies, multinational companies are more induced to investing in fast emerging countries with domestic credit constraints. The impact of trade openness has a Kuznets shape from the $0.25^{\text {th }}$ to the $0.75^{\text {th }}$ quantile for Gross FDI and increasing for Net FDI. Hence, it could broadly be established that for the latter, the benefits of FDI from trade openness increases with higher initial levels of FDI.

There is a threshold effect from political stability for the $0.10^{\text {th }}, 0.25^{\text {th }} \& 0.90^{\text {th }}$ quantile. As a policy implication the FDI benefits from political stability depend to some extend on existing levels of FDI. This substantially contrasts with the findings of Jadhav \& Katti (2012) on the BRICS, in which political stability is a negatively insignificant driver of FDI. 


\section{References}

Abdioglu, N., Khurshed, A., \& Stathopoulos, K., (2013). "Foreign institutional investment: Is governance quality at home important?", Journal of International Money and Finance, 32, pp. 916-940.

Akpan, U. S., Isihak, S. R., \& Asongu, S. A., (2014). "Determinants of Foreign Direct Investment in Fast-Growing Economies: A Study of BRICS and MINT", African Governance and Development Institute Working Paper No. 14/002.

Aleksynska, M., \& Havrylchyk, O. (2013). "FDI from the south: The role of institutional distance and natural resources”. European Journal of Political Economy, 29, pp. 38-53.

Amendolagine, V., Boly, A., Coniglio, N. D., Prota, F., \& Seric, A., (2013). "FDI and Local Linkages in Developing Countries: Evidence from Sub-Saharan Africa", World Development, 50, pp. 41-56.

Anyanwu, J., (2013). "Determining the Correlated of Poverty for Inclusive Growth in Africa", African Development Bank Working Paper No. 181.

Anyanwu, J., (2012). "Why Does Foreign Direct Investment Go Where It Goes?: New Evidence From African Countries", Annals of Economics and Finance, 13(2), pp. 425-462.

Anyanwu, J., \& Augustine, D., (2013). “Gender Equality in Employment in Africa: Empirical Analysis and Policy Implications”, African Development Review, 25(4), pp. 400-420.

Arezki, R., Deininger, K., \& Selod, H., (2013). “What drives the global land rush?”, The World Bank Economic Review, http://wber.oxfordjournals.org/content/early/2013/10/21/wber.lht034

Asiedu, E., (2002). "On the Determinants of Foreign Direct Investment to Developing Countries: Is Africa Different?”, World Development, 30, pp. 107-119.

Asiedu, E., (2006). "Foreign Direct Investment in Africa: The Role of Natural Resources, Market Size, Government Policy, Institutions and Political Instability". The World Economy, 29, pp. 63-77.

Asiedu, E., \& Lien, D. (2011). "Democracy, foreign direct investment and natural resources". Journal of International Economics, 84, pp. 99-111.

Asongu, S. A., (2012), "Government quality determinants of stock market performance in African countries”, Journal of African Business, 13(2), pp. 183-199.

Asongu, S. A., (2013a). "Fighting consumer price inflation in Africa: what do dynamics in money, credit, efficiency and size tell us", Journal of Financial Economic Policy, 5(1), pp. 39-60.

Asongu, S. A., (2013b). "Fighting corruption in Africa: do existing corruption-control levels matter?", International Journal of Development Issues, 12(1), pp. 36-52. 
Asongu, S. A., (2013c). "How Would Population Growth Affect Investment in the Future? Asymmetric Panel Causality Evidence for Africa", African Development Review, 25(1), pp. 14-29.

Asongu, S. A., (2014a). "Correcting Inflation with Financial Dynamic Fundamentals: Which Adjustments Matter in Africa?", Journal of African Business, 15(1), pp. 64-73.

Asongu, S. A., (2014b). "The impact of health worker migration on development dynamics: evidence of wealth effects from Africa", The European Journal of Health Economics, 15(2), pp. 187-201.

Asongu, S. A., \& Aminkeng, G. A. A., (2013). "The economic consequences of China-Africa relations: debunking myths in the debate", Journal of Chinese Economic and Business Studies, 11(4), pp. 261-277.

Asongu, S.A. \& Nguena, C.L. (2015). Equitable and Sustainable Development of Foreign Land Acquisitions: Lessons, Policies, and Implications. In E. Osabuohien (Ed.), Handbook of Research on In-country Determinants and Implications with Foreign Land Acquisitions (pp.120). New York: IGI Global.

Bartels, F. L., Alladina, S. N., \& Lederer, S., (2009).“Foreign Direct Investment in SubSaharan Africa: Motivating Factors and Policy Issues”, Journal of African Business, 10(2), 141-162.

Bartels, F. L. Napolitano, F., \& Tissi, N. E., (2014). "FDI in Sub-Saharan Africa: A longitudinal perspective on location-specific factors (2003-2010)", International Business Review, 23(3), pp. 516-529.

Billger, S. M., \& Goel, R. K., (2009), “Do existing corruption levels matter in controlling corruption? Cross-country quantile regression estimates", Journal of Development Economics, 90, pp. 299-305.

Buchanan, B. G., Le, Q. V., \& Rishi, M., (2012). "Foreign direct investment and institutional quality: Some empirical evidence”. International Review of Financial Analysis, 21, pp. 8189.

Buckley, P., \& Casson, M. (1976). The Future of the Multinational Enterprise. London: Homes \& Meier.

Busse, M., \& Hefeker, C. (2007). Political risk, institutions and foreign direct investment. Accessed 19.11.2012.

Büthe, T., \& Milner, H. V., (2008). "The Politics of Foreign Direct Investment into Developing Countries: Increasing FDI through International Trade Agreements?", American Journal of Political Science, 52 (4), pp. 741-762. 
Clapp, J., (2013). "Financialization, Distance and Global Food Politics", International Conference, Yale University, September 14-15.

http://www.tni.org/sites/www.tni.org/files/download/5_clapp_2013.pdf

Cleeve, E., (2012). "Political and Institutional Impediments to Foreign Direct Investment Inflows to Sub-Saharan Africa”. Thunderbird International Business Review , 54 (4), pp. 469477.

Collier, P., (2008). "The Politics of Hunger How Illusion and Greed Fan the Food Crisis." Foreign Affairs, 87 (6): 6

Darley, W. K., (2012). “Increasing Sub-Saharan Africa's Share of Foreign Direct Investment: Public Policy Challenges, Strategies, and Implications", Journal of African Business, 13(1), pp.62-69.

De Janvry, A., \& Sadoulet, E., (2010). “Agricultural Growth and Poverty Reduction:

Additional Evidence.” World Bank Research Observer, 25 (1), pp. 1-20.

Economic Commission for Africa (2004). "Land Tenure Systems and their Impacts on Food Security and Sustainable Development in Africa", ECA/SDD/05/09.

Eiteman, D. K., Stinehill, A. I., \& Moffett, M. H. (2007). Multinational Business Finance (11th ed.). Boston: Pearson Addison Wesley.

Fairbairn, M., (2013). "'Like gold with yield': Evolving intersections between farmland and finance". International Conference, Yale University, September 14-15.

http://www.tni.org/sites/www.tni.org/files/download/6_fairbairn_2013.pdf

Gastanaga, V. M., Nugent, J. B., \& Pashamova, B. (1998). "Host country reforms and FDI inflows: How much difference do they make?", World Development, 26 (7), pp. 1299-1314.

German, L., Schoneveld, G., Mwangi, E., (2011). "Processes of Large-Scale Land Acquisition by Investors: Case Studies from Sub-Saharan Africa", Paper presented at the International Conference on Global Land Grabbing 6-8 April 2011.

Hajzler, C., (2014). "Resource-based FDI and expropriation in developing economies". Journal of International Economics, 92 (1), pp. 124-146.

Hennart, J. (1982). A theory of multinational enterprise. Ann Arbor: University of Michigan.

Ingwe, R., Okoro, J., \& Ukwayi, J. K., (2010). "The New Scramble for Africa: How LargeScale Acquisition of Sub-Saharan Africa's Land by Multinational Corporations and Rich Countries Threaten Sustainable Development", Journal of Sustainable Development in Africa, 12(3), pp. 28-50.

Isakson, R., (2013). "Financialization and the Transformation of Agro-food Supply Chains: A Political Economy". International Conference, Yale University, September 14-15. http://www.tni.org/sites/www.tni.org/files/download/9_isakson_2013.pdf 
Jadhav, P., (2012). "Determinants of Foreign Direct Investments in BRICS Economies: Analysis of Economic, Institutional and Political Factors". Procedia-Social and Behavioral Sciences , 37, 5-14.

Jadhav, P., \& Katti, V., (2012). "Institutional and Political Determinants of Foreign Direct Investment: Evidence From BRICS Economies". Poverty \& Public Policy , 4 (3), 49-57.

Kinda, T., (2010). "Investment Climate and FDI in Developing Countries:Firm-Level Evidence", World Development, 38(4), pp. 498-513.

Kindlerberger, C. (1969). American Business Abroad: Six Lectures on Direct Investment. New Haven: Yale University Press.

Koenker, R., \& Bassett, Jr. G., (1978),“Regression quantiles“, Econometrica, 46, pp.33-50.

Koenker, R., \& Hallock, F.K., (2001), “Quantile regression”, Journal of Economic Perspectives, 15, pp.143-156.

Kolstad, I., \& Wiig, A., (2011). "Better the Devil You Know? Chinese Foreign Direct Investment in Africa", Journal of African Business, 12(2), 31-50.

Lay, J., \& Nolte, K., (2014). "Land grabs or simply investments? Determinants of foreign large scale land acquisitions in developing countries", GIGA German Institute of Global and Area Studies, Hamburg, Germany, and University of Göttingen.

Lipton, M., (2009). Land Reform in Developing Countries: Property Rights and property Wrongs. New York: Routledge (or Taylor and Francis).

Liu, P., (2013). "Impacts of foreign agricultural investment on developing countries: evidence from case studies", Food and Agricultural Organization;

file://C:/Users/user/Downloads/Liu\%20(1).pdf

Loayza, N. V., \& Raddatz, C., (2010). “The composition of growth matters for poverty alleviation." Journal of Development Economics, 93 (1), pp. 137-51.

Moosa, I. (2002). Foreign Direct Investment: Theory, Evidence and Practice. London: Palgrave.

Moosa, I. A., \& Cardak, B. A. (2006). "The determinants of foreign direct investment: An extreme bounds analysis". Journal of Multinational Financial Management, 16, pp. 199-211.

Neumayer, E., \& Spess, L., (2005). "Do bilateral investment treaties increase foreign direct investment to developing countries?", World Development, 33 (10), pp. 1567-85.

Okada, K., \& Samreth, S.,(2012), "The effect of foreign aid on corruption: A quantile regression approach", Economic Letters, 115(2), pp. 240-243. 
Okoth-Ogendo, H. W. (2008). The Last Colonial Question: An essay in the pathology of land administration systems in Africa. In: Helge Onsrud and Elena Busch (eds.) Norwegian Land Tools Relevant to Africa Report, of a Workshop organized by the Norwegian Mapping and Cadastre Authority, 3-4 May 2007, Oslo (Norway), Hpnefoss: Norwegian Mapping and Cadastre Authority, February: 37-46

Osabuohien, E. S., (2014). "Land-scale agricultural land investments and local institutions in Africa", Land Use Policy, 39, pp. 155-165.

Osabuohien, E. (Ed.) (2015).Handbook of Research on In-country Determinants and Implications with Foreign Land Acquisitions. New York: IGI Global.

Ranjan, V., \& Agrawal, G. (2011). "FDI Inflow Determinants in BRIC countries: A Panel Data Analysis". International Business Research, 4 (4), pp. 225-263.

Rogmans, T., \& Ebbers, H. (2013). "The determinants of foreign direct investment in the Middle East North Africa region". International Journal of Emerging Markets, 8 (3), pp. 240257.

Rolfe, R. J., \& Woodward, D. P., (2004). "Attracting foreign investment through privatization: the Zambian experience", Journal of African Business, 5(1), pp.5-27.

Sekkat, K., \& Veganzones-Varoudakis, M.-A., (2007). "Openness, Investment Climate, and FDI in Developing Countries". Review of Development Economics , 11 (4), pp. 607-620.

Shapiro, C. A. (2006). Multinational Financial Management (8th ed.). United States of America: Jonh Wiley \& Sons, Inc.

Suliman, A. H., \& Mollick, V. A. (2009). "Human Capital Development, War and Foreign Direct Investment in Sub-Saharan Africa”. Oxford Development Studies, 13 (1), pp.47-61.

Thaler, K., (2013). "Large-Scale Land Acquisitions and Social Conflict in Africa". International Conference, Yale University, September 14-15.

http://www.tni.org/sites/www.tni.org/files/download/22_thaler_2013.pdf

Tuomi, K., (2011). "The Role of the Investment Climate and Tax Incentives in the Foreign Direct Investment Decision: Evidence from South Africa", Journal of African Business, 12(1), pp.133-147.

United Nations (2010, January). "Foreign land purchases for agriculture: what impact on sustainable development?", Sustainable Development and Innovation Briefs Issue No. 8.

UNCTAD. (2002). World Investment Report: Transnational Corporations and Export Competitiveness. New York: United Nations.

UNDP. (2013). Human Development Reports. Retrieved January 26, 2014, from United Nations Development Programme:

http://www.undp.org/content/dam/undp/library/corporate/HDR/2013GlobalHDR/English/HD $\underline{\text { R2013\%20Report\%20English.pdf }}$ 
Vijayakumar, N., Sridharan, P., \& Rao, K. C., (2010). "Determinants of FDI in BRICS Countries: A panel analysis". Int. Journal of Business Science and Applied Management , 5 (3), pp.1-13.

Wei, S.-J. (2000). "How Taxing is Corruption on International Investors?" Review of Economics and Statistics, VOL. LXXXII, No.1, pp. 82, 1-11.

World Bank. (2007). Agriculture for Development: World Development Report 2008.

Washington, D.C.: World Bank and Oxford University Press.

World Bank. (2013). World Development Indicators. UK Data Service. Retrieved January 23, 2014, from World Bank.

Wouterse, F., Deininger, K., Selod, H., Badiane, O., Swinnen, J., Von Braun, J., \& Zilberman, D., (2011). "Foreign Direct Investment in Land in West Africa: The Status Quo, Lessons from Other Regions, Implications for Research", West \& Central Africa Office Thematic Research Note 1.

Yin, J. Z., \& Vaschetto, S., (2011). “China's Business Engagement in Africa”, The Chinese Economy, 44 (2), pp. 43-57. 